\title{
Planning for foreign policy: a framework for analysis
}

By: Linda P. Brady

Brady, Linda. "'Planning for Foreign Policy: A Framework for Analysis," in International Journal, Vol. XXXI I, no. 4 (Autumn 1977), pp. 829-848.

\section{****Note: Figures may be missing from this format of the document}

'Avoid trivia.' Such was the advice given to George F. Kennan, first director of the Policy Planning Staff $(\mathrm{s} / \mathrm{P})^{1}$ of the United States Department of State by the Secretary of State, George C. Marshall. The staff was created by Marshall in April 1947 in response to perceived threats of economic collapse and political chaos in postwar Europe. Kennan and his five-man staff assumed active roles in the formulation of the Marshall Plan, attesting to their acceptance of Marshall's advice. The effects of the plan were not only to speed immediate European economic recovery, but also to lay the foundation for future European economic prosperity. ${ }^{2}$ In this situation the Policy Planning Staff had a dramatic impact on the direction of American foreign policy. The powerlessness of the staff in the formulation of United States policy in Vietnam during the early and mid-1960s provides a striking contrast. Although Director Walt Rostow instituted the National Policy Papers as strategies for developing innovative policy guidelines, his efforts went unheeded by the Secretary of State, Dean Rusk. According to many observers, the influence of the Policy Planning Staff dropped to the lowest point in its history during the 1961-6 period, and particularly with respect to Vietnam policy. ${ }^{3}$

What has made the difference between success and failure for the Policy Planning Staff over time? Why has it had an impact on policy in some situations but not in others? More generally, what does the staff's experience tell us about the conditions under which planners can influence the direction of foreign policy?

These questions are not new. From its formation in 1947, through its enlargement and bureaucratic upgrading in 1961 and its transformation during 1969, to its rejuvenation in 1973 with Henry Kissinger's move to the Department of State and Winston Lord's appointment as director, the Policy Planning Staff has generated extensive discussion, research, and commentary concerning its effectiveness in the policy-making process. Staff members and directors, secretaries of state, academic observers, and government reformers on numerous occasions have evaluated the State planning group. What consensus can be identified suggests a mixed record of performance since the resignation of George Kennan in September 1949 over the issue of independent S/P access to the secretary of state.

1. The title of this group has varied since its formation. The staff's title was changed to Policy Planning Council in 1961, to Planning and Coordination Staff in 1969, and back to the Policy Planning Staff in 1973. Throughout this article I will refer to the group as the Policy Planning Staff, regardless of the period under discussion.

2. For extended discussions of sir. participation in the formulation of the Marshall Plan, see: Dean Acheson, Present at the Creation (New York 1969); Irving L. Janis, Victims of Groupthink (Boston 1972); Joseph Marion Jones, The Fifteen Weeks (New York 1955); and George F. Kennan, Memoirs: 1925-1950 (Boston 1967).

3 Sip failure to influence Vietnam policy during the early 1960s is documented in: Chester L. Cooper, The Lost Crusade - America in Vietnam (New York Iwo), p 415; I.M. Destler, 'National Security Advice to u.s. Presidents: Some Lessons from Thirty Years,' World Politics, xxix (January ${ }^{1} 977$ )' 154; and Townsend Hoopes, The Limits of Intervention (New York ig6g), $\mathrm{p} 1$.

4 For views of participants, see: Acheson, Present at the Creation; Robert R. Bowie, Shaping the Future: Foreign Policy in an Age of Transition (New York 1964); Kennan, Memoirs; and Walt W. Rostow, 'The Planning of Foreign Policy' in E.A.J. Johnson, ed, The Dimensions of Diplomacy (Baltimore 1964). Insightful academic studies are represented by: Lincoln P. Bloomfield, 'Organizing for Policy Planning' (prepared for the Commission on the Organization of the Government for the Conduct of Foreign Policy 1975); I.M. 
There is less consensus on the causes of the staff's mixed record. Some observers have placed the blame for S/P failure on the head of the secretary of state. Although he viewed Marshall as his professional ideal, Dean Rusk, for example, failed to encourage the long-range planning activities supported by his role model.' Critics of the planning process under Rusk agree that he focused too much on the problems of the day, to the neglect of potentially significant but less immediate issues.' The Policy Planning Staff's mode of operation during Rusk's tenure compounded this neglect: generally, the staff (under the directorship of Rostow) met only every three or four weeks to discuss a planning paper which the Secretary might not have read.? It is difficult to resist the conclusion that during the early 1960 s the staff exercised little influence on American foreign policy.

Another explanation of sip failure to influence American foreign policy rests on the changing nature of its responsibilities. In July 1969 Under Secretary of State Elliott Richardson announced the formation of the Planning and Coordination Staff as a replacement for the Policy Planning Council. SiP members were divided between a planning group that concerned itself with longrange problems and a co-ordination group that focused on immediate policy decisions. In addition to analysis of current issues and the encouragement of debate, the reorganized staff assumed responsibility for management of the department's input into the National Security Council system. By 1971 it was clear that the staff's impact on policy-making had been minimal. Two frequently mentioned reasons for that lack of influence are the shift in s/P responsibilities from planning to operations and the shift of the remaining planning functions from staff to line agencies. ${ }^{8}$

The behaviour of the secretary of state and the nature of s/p responsibilities are but two of many factors cited for the Policy Planning Staff's mixed record in the postwar period. The main purposes of this article are to identify a range of influences on staff behaviour and to suggest empirically testable propositions that relate these influences to staff impact on foreign policy. A further aim is to cast these propositions in a form that allows their application to planners outside $\mathrm{s} / \mathrm{P}$ and to planners in non- American foreign-policy-making institutions. To achieve these goals it is necessary to address two questions: what is planning? when are planners influential?

\section{WHAT IS PLANNING?}

When he created the Policy Planning Staff, Secretary Marshall defined the functions of the group in broad terms. As revealed by Kennan in his memoirs, 'the Staff was to formulate "long-term programs for the achievement of U.S. foreign policy objectives;" to involve itself in "anticipating problems which the department may encounter in the discharge of its mission;" to undertake and prepare studies on "broad politico-military

Destler, Presidents, Bureaucrats, and Foreign Policy: The Politics of Organizational Reform (Princeton 1972), pp 214-53; and Robert L. Rothstein, Planning, Prediction and Policymaking in Foreign Affairs (Boston 1972).

5 Hoopes, The Limits of Intervention, $\mathrm{p} 1$.

6 On this point, see John P. Leacacos, Fires in the In-Basket (New York 1968), p 106, and Daniel Madar, 'Planners, Influence, and Bureaucracy,' International Journal, xxx (winter 1974-5), 68.

7 In fairness to Rusk, however, it should be noted that during the period 1961-6 members of the staff produced 339 papers, averaging 50 pages in length. In one year, 1964, staff members produced 71 papers (Leacacos, Fires in the In-Basket, p 533). It is unlikely that any secretary would have been able to read all of the material generated by the staff during this period.

8 Destler, Presidents, Bureaucrats, and Foreign Policy, p 215. 
problems;" "to evaluate the adequacy of current policy" and to make advisory recommendations on it; and, finally, to coordinate planning activities within the State Department. ${ }^{9}$

In spite of this charge to the staff, or perhaps because of its internal contradictions, there has been little agreement on the responsibilities of members of the Policy Planning Staff. In the same breath, Marshall encouraged the staff to focus on long-term and on current policy, to anticipate problems and to evaluate present policy, to formulate objectives and to define instruments of policy, to remain aloof from the political process and to coordinate activities within the Department of State. This controversy over the nature of planning functions has been expressed as two alternative perspectives: planning as intellectual activity versus planning as political process.

\section{Planning as intellectual activity}

In its most pure form, the 'thinker' model $\sim$ planning as intellectual activity $\sim$ focuses on what planners should do. From this perspective, planning is the performance of specified (intellectual) functions. Schelling sums up these functions in the form of a question: 'How do you make a list of things you would never have thought of? ${ }^{10}$ Bloomfield goes further, clustering planning responsibilities into four groups: conceptualization, anticipation, postaudit, and challenge. ${ }^{11}$ Conceptualization requires the definition of broad national interests, goals, and objectives. Anticipation involves forecasting events and situations. Post-audit demands the post-hoc analysis of strategies. And challenge, perhaps the most difficult function to perform, includes the explicit formulation of adversary arguments.

Note the distinction between planning and operations which is implicit in the 'thinker' model of foreign-policy planning. Planning staff responsibilities are limited to the formulation of objectives, forecasting, post-hoc analysis, and the formulation of 'unthinkable' altematives. At no point does the staff become an active lobbyist for its proposals. Nor does the staff serve as co-coordinator of goal- setting or option-formulation activities performed by other bureaucratic actors. The principal reasons for staff aloofness are clear by involving itself in operations the staff sacrifices its longterm perspective and compromises its adversary role in the policy process. When asked to define planning many planners adopt this perspective $\sim$ planning is not responding to cables, not coordination, and not speech writing. 12

\section{Planning as political process}

The second perspective on foreign-policy planning has much in common with the first. Like the 'thinker' model, the 'bureaucratic actor' model defines planning as the performance of specified functions: formulation of objectives, forecasting, post-hoc analysis, and the formulation of unthinkable alternatives. Like the intellectual perspective, also, the political process perspective recognizes the distinction between planning functions and operational responsibilities.

But, unlike the 'thinker' model, the 'bureaucratic actor' model assumes that foreign-policy planning cannot be understood outside of the political context in which it occurs. As Robert Bowie, director of the Policy Planning Staff during one of its most successful periods, has put it: "The purpose of a policy planning staff is not merely to produce literature, but to produce results. ${ }^{13}$ In short, what matters most is influence. Planning has an impact on policy only if planners are influential. Planners are not only thinkers, but also actors in a bureaucratic game. Thus planning will be influential only when it is supported and pushed with the political skills of a bureaucrat. ${ }^{14}$

10 Cited in Lincoln P. Bloomfield, The Foreign Policy Process: Making Theory Relevant (Beverly Hills 1974), p 122.

11 Bloomfield, 'Organizing for Policy Planning,' p 4.

12 Lincoln P. Bloomfield, 'Planning Foreign Policy: Can It Be Done? What the Planners Really Think' (paper prepared for the annual meetings of the International Studies Association 1976), pp 2-13.

13 Cited in 'Planning in the Department,' Foreign Service Journal, xxxvI I I (March 1961), 24.

14 On the general issues of bureaucratic politics, see Morton H. Halperin, Bureaucratic Politics and Foreign Policy (Washington 1974). For an application of the bureaucratic politics literature to foreign-policy planning, see Richard K. Betts, 'Planning Staffs, Bureaucratic Politics, and Influence in Foreign Policy' (Cambridge 1973), p 19. 
This means, of course, that planners must have access to information and to high-level decision-makers. Such access is acquired through manipulation of the bureaucratic process. Bargaining skills and advantages suggested by Destler include 'involvement in regular action processes, such as budget review or cable clearance; access to or control over information; alliance with foreign government counterparts or domestic constituencies; [and] the confidence of other important officials as well as that of the President ... ${ }^{15}$ If they do not hold at least several bargaining chips vis-a-vis other bureaucratic actors, planners are unlikely to influence policy.

Consider, for example, the active participation of the Policy Planning Staff in the development of multilateral force proposals during the early 1960s. The success of staff members, particularly Bowie and Owen, in influencing Kennedy's thinking on the multilateral force was due in part to their access to the White House through the special assistant for national security affairs, McGeorge Bundy, and to the sympathy of George Ball, under secretary of state: 'Throughout 1961, State's policy planners, granted occasional and politically important access to the White House for briefings, worked on the idea of partnership as the central theme in European pol icy. ${ }^{16}$

But this does not mean that planners must become operators in order to influence policy. Planners may become engaged in the policy process without assuming operational responsibilities on a dayto-day basis. Stanley Hoffmann has suggested that 'planning should be "action-oriented" yet separate from daily operations. ${ }^{17}$ In his explanation of the influence of the policy planning staff within the Office of the Assistant Secretary of Defense for International Security Affairs, Yarmolinsky has noted that the 'staff examined the long-range planning implications of immediate decisions facing the department, but it did so always in the context of a matter that was very much at the top of the Assistant Secretary's immediate priority list. It did not produce policy papers in vacuo, but rather made recommendations for action in areas where the Assistant Secretary and the Secretary were prepared to act.

\section{Planning as a balance of the intellectual and the political}

There are no easy ways of resolving the conflict between planning as intellectual activity and planning as political process. The political process model argues that planners are successful only when they walk a narrow line between planning and operational responsibilities. On the one hand, as planners engage themselves in the political process they risk losing their detachment. But, on the other hand, if planners isolate themselves from the political process they run the greater risk of engaging in mere intellectual exercises. All of this suggests why there is so little consensus on the responsibilities of planners.

Although neither of the two perspectives is completely satisfactory, I have adopted the second. For the purpose of this study, planning is viewed as multiple intellectual activities performed in the context of a political process.

\section{WHEN ARE PLANNERS INFLUENTIAL?}

The analysis of planner influence on foreign policy begins with a question that has long plagued students of politics: what is influence? What emerges from the literature on foreign-policy decision-making is a

15 Destler, Presidents, Bureaucrats, and Foreign Policy, $p 58$.

16 John D. Steinbruner, The Cybernetic Theory of Decision (Princeton 1974), p 223.

17 Stanley Hoffmann, Gulliver's Troubles, Or the Setting of American Foreign Policy (New York 1968), p 317. 
conception of influence as the power to persuade. ${ }^{20}$ Influence, in the context of this study, means getting the president to do something he might not have done otherwise. '18 More recently, particular types of engagement in the policy-making process, such as speech writing, have been encouraged both by outside observers and by members of the Policy Planning Staff in the Department of State. ${ }^{19}$

One of the most troublesome problems in the analysis of influence is the construction of valid indicators. How do we know when influence has been exerted? In this case I have assumed that the effects of Policy Planning Staff participation in the foreign- policy process will be reflected in statements and actions by members of the executive branch. If a staff proposal is accepted by the executive, at some point that proposal, or a modified form of it, should appear in an executive policy proposal. As one approach to indicator construction, I suggest that the frequency of these appearances indicates the extent of S/P influence on foreign policy. But influence is not a unidimensional concept; it has at least two elements: weight and scope. ${ }^{21}$ Weight is the degree, extent, or form of participation in the policy-making process. As the weight of Policy Planning Staff influence increases, the probability that its perspectives will be accepted increases as well. Scope refers to the number and kinds of issues, policies, decisions, or values affected by participation. The scope of staff influence widens as it becomes involved in policy-making on an increasingly wide range of issues.

Beyond those associated with defining influence, there are major difficulties in the isolation of the causes of S/P influence or lack of influence on foreign policy. Most analyses of the Policy Planning Staff have taken the form of highly impressionist case- studies or memoirs. While not denying the value of memoirs and intensive analyses of single cases, there are advantages to a more systematic approach to the explanation of planning group influence. Rather than focusing on a single issue, director, or secretary of state, I have identified three classes of influences: individual characteristics of S/P directors and members, organizational- bureaucratic factors, and contextualsituational influences. These influences operate in all cases of planning group participation in the policy process, and they provide a means of evaluating the impact of a planning group over time.

Individual characteristics include background personal and social characteristics of staff members, recruitment patterns, and the operating styles of s/P directors. The organizational- bureaucratic cluster includes variables ranging over the relationship between the staff, the director, and the secretary of state, the relationship between the staff and regional and functional bureaux within the Department of State, the rise of competing organizational structures such as the National Security Council planning group, staff access to intelligence information, and the scope of staff responsibilities. Finally, contextual or situational influences include the nature of the situation confronting policy-makers and the substantive issues with which policy is concerned.

18 Adam Yarmolinsky, 'Bureaucratic Structures and Political Outcomes,' Journal of International Affairs, xxiii (1969), 232.

19 For an observer's viewpoint, see Halperin, Bureaucratic Politics and Foreign Policy, p 190. Jan Kalicki, a onetime member of the Policy Planning Staff, has suggested that speech writing for the secretary often provides the planner with a unique opportunity to inject a long-range perspective into the policy process.

20 The classic statement of 'the power to persuade' is Richard E. Neustadt's Presidential Power: The Politics of

Leadership (New York 1960). For applications of this definition to defence and strategic issues see Samuel P.

Huntington, The Common Defense: Strategic Programs in National Defense (New York 1961) and Roger Hilsman, To Move a Nation: The Politics of Foreign Policy in the Administration of John F. Kennedy (New York 1967). 
While serving as the first director of the Policy Planning Staff under Secretary Marshall, George Kennan held almost daily meetings with his staff. ${ }^{22}$ During the $1973-6$ period Winston Lord reserved Fridays for meetings with the staff to discuss projects and papers in progress. ${ }^{23}$ In contrast, Walt Rostow, who was staff director from 1961 to 1966, held only infrequent meetings with his staff. ${ }^{24}$ How might these various operating styles contribute to the influence or lack of influence of the s/P on foreign policy? The operating style of a director influences his ability to utilize the intellectual resources of his staff members. If a director avoids political interchange and interacts with staff members on an individual

These dimensions of influences are presented in James A. Robinson, Congress and Foreign PolicyMaking (Homewood, III, 1967), pp 4-6. basis rather than as a group, then the group is less likely to develop a 'sense of self.' That is, infrequent meetings of the group interfere with group cohesion and the perception of the group as an independent bureaucratic actor. These conditions, in turn, decrease the staff's influence because they put the staff in a disadvantageous bargaining position vis-a-vis other bureaucratic actors. ${ }^{25}$ Thus the operating style of a director can have a dramatic impact on the staff's influence in the policy process. It is not surprising, given this argument, that most observers have viewed S/P planning under Kennan and Lord as more successful than under Rostow, other things being equal.

Planning Staff under Rusk has been viewed as less influential than the staff under Kissinger, specifically because of the absence of a close personal relationship between Rusk and Rostow in the first instance, and the presence of a close personal relationship between Kissinger and Lord in the second. ${ }^{26}$

But other things rarely are equal. Organizational-bureaucratic factors have been cited more often than individual characteristics as reasons for the presence or absence of S/P influence on foreign policy. Included in this class of influences is the personal relationship between the director and the secretary of state. The Policy To take another example, Kennan reports of his relationship with Marshall that from May 1947 until late 1948 he had the only office adjoining the Secretary's and that he enjoyed the privilege of direct entry through a common side door.$^{27}$ Rothstein has summarized this relationship in the form of a proposition: 'success or failure for a planning staff depends not on what it does, or who is on it, or where it is placed, but on the willingness of the Secretary of State to listen to it, to consult it, and to protect it from enemies. ${ }^{128}$ Needless to say, the Kennan and Lord staffs were listened to, were consulted, and were protected by their respective secretaries of state.

Another frequently cited organizational-bureaucratic factor is the scope of planning group responsibilities: that is, the extent to which the group engages in operations as well as planning activities. The replacement of the Policy Planning Council by the Planning and Coordination Staff in 1969 so overloaded the sip with administrative responsibilities that it was unable to exert much impact on the substance of American foreign policy.

22 Janis, Victims of Groupthink, p 170.

23 Communication from James M. Patton, member of the Policy Planning Staff.

24 Leacacos, Fires in the In-Basket, p 533.

25 Halperin, Bureaucratic Politics and Foreign Policy, $p 54$.

26 On the Rusk-Rostow relationship, see Destler, 'National Security Advice to U.S. Presidents,' $p 154$.

Information on the Kissinger-Lord relationship was obtained from several members of the Policy

Planning Staff.

27 Destler, Presidents, Bureaucrats, and Foreign Policy, p 225. However, physical access is not a sufficient condition for influence. Bowie's adjoining office to Dulles failed to increase the staff's influence.

28 Rothstein, Planning, Prediction and Policymaking in Foreign Affairs, p 60. 
Clearly these reforms interfered with the aims of policy planners. Instead of focusing on the definition of goals and objectives, the evaluation of past strategies, and the anticipation of problems and opportunities presented by emerging situations, the S/P turned its attention to coordination and exchanged an adversary policy role for managerial responsibility. Moreover, the man appointed to head the new group William Cargo had neither a prior personal relationship with the secretary of state nor recent high-level bureaucratic experience in Washington. ${ }^{29}$

\section{ILLUSTRATIVE PROPOSITIONS}

As I have suggested, understanding the problem of why the Policy Planning Staff has been influential in some situations and not in others requires more than the identification of specific instances of influence or lack of influence. My approach is to isolate a number of factors drawn from the analysis of specific cases and to formulate empirically testable propositions that relate these factors to the weight and scope of staff influence. Thus, although individual cases provide the foundation for these propositions, the propositions themselves apply across time and across situations. The purpose here is not to be exhaustive but to be illustrative. Each proposition is accompanied by a brief rationale.

\section{PROPOSITION 1}

The more 'promotive' the operating style of the director, the greater the weight and the broader the scope of the influence of the Policy Planning Staff.

Individual characteristics of the director of the Policy Planning Staff may have a profound impact on the group's activities. In particular, if the director adopts an activist role, that is if he is the operating style of Gerard Smith, director of the Policy Planning Staff from 1957 to 1961, and the staffs impact on foreign policy during that time, support the 'promotive' hypothesis. Smith believed the staff had to advertise to be effective. In his words, ideas in a bureaucracy especially when they call for change in policy $\sim$ need extensive promotion. ${ }^{31}$ Unless the director is willing to take the initiative and to involve himself in bureaucratic interaction both within the Department of State and between that department and other agencies, the Policy Planning Staff will not affect the direction of policy. ${ }^{32}$ During Smith's tenure, the staff played an extensive role in the development of the Hot Line and in the formulation of the Alliance for Progress, both significant policies with major impacts.

\section{PROPOSITION 2}

The closer the personal relationship between the director and the secretary of state, the greater the weight of S/P influence.

\section{PROPOSITION 3}

The closer the personal relationship between the director and the secretary of state, the more the scope of S/P influence will reflect the specific policy interests of the secretary of state. (That is, if the secretary of state is concerned with a wide range of policy issues and if the secretary and the director enjoy a close personal relationship, then the scope of S/P influence will be broad.)

29 Destler, Presidents, Bureaucrats, and Foreign Policy, p 218.

30 Rothstein, Planning, Prediction and Policymaking in Foreign Affairs, $p 56$.

31 Cited in Grant T. Hammond, 'The Policy Planning Council and Planning in Foreign Policy' (mimeo 1968), $p$ 24.

32 lbid,p 25. 
The relationship between the director of the Policy Planning Staff and the secretary of state probably is cited more frequently than any other influence on the operation of the staff. ${ }^{33}$ If the secretary takes the director seriously, then he is likely to be persuaded by staff arguments; consequently, other bureaucratic actors (including the president) are likely to take the staff seriously. A close working relationship between the two men, then, almost guarantees that the staff will participate frequently in policy debates that carry potential significance.

The linkage between personal relationship and scope of $\mathrm{s} / \mathrm{P}$ influence is less direct. Because of this close relationship, the staff is likely to consider those problems that interest the secretary of state. If he is concerned with a wide range of issues, then the scope of staff influence will also be broad. If only a few issues occupy the secretary's agenda, then only these issues are likely to be on the staff's agenda.

Henry Kissinger's move to the Department of State in 1973 and his appointment of Winston Lord as director of the Policy Planning Staff support these propositions. During Lord's tenure the status, activity, and impact of the staff increased measurably, due in no small part to the longstanding close personal relationship between Lord and Kissinger. (Lord had accompanied Kissinger on the early, secret trips to Peking and served as an aide on the staff of the National Security Council.) Because of Kissinger's major interest in politico-military issues, $\mathrm{S} / \mathrm{P}$ members tended to concentrate their efforts initially in those areas. This drift toward a narrow substantive scope was countered to some extent by Lord's insistence that at least half of the staff concentrate on economic problems. Quite clearly this shift illustrates the interaction of organizational- bureaucratic factors and individual characteristics. In this instance, Lord's conviction that economic problems would occupy an increasingly significant place on America's foreign-policy agenda, in combination with Kissinger's newfound interest in economic issues following the 1973 oil crisis, enabled the Policy Planning Staff to broaden the scope of its influence.

\section{PROPOSITION 4}

When policy-makers are faced with a crisis situation, the scope of S/P influence narrows. PROPOSITION 5

When policy-makers are faced with a crisis situation, the weight of S/P influence depends upon its bureaucratic relationship to the secretary of state. The closer the personal relationship between the staff and the secretary, the greater the weight of staff influence in a crisis.

Situational variables operate as indirect, albeit significant, influences on the operation of policy planning groups. When decision- makers perceive crisis situations as occasions for decision, they tend to make adjustments in routine organizational processes. For example, decisions tend to be made by fewer and higher level bureaucratic participants, and ad hoc decisional units tend to replace formal organizational structures." Under these conditions the Policy Planning Staff, if it participates to any degree, will focus on the issue at hand. Given the nature of crisis situations (that is, circumstances that represent threats to major goals or objectives), the scope of staff participation is likely to be constrained.

33 For example, see: Kennan, Memoirs; Madar, 'Planners, Influence, and Bureaucracy'; and Donald P. Warwick, A Theory of Public Bureaucracy: Politics, Personality, and Organization in the State Department (Cambridge 1975). 
The extent to which the Policy Planning Staff participates in the decision-making process during a crisis (the weight of its influence) varies with the relationship between the staff and the secretary of state (see PROPOSITION 2). If the staff is tied closely to the secretary, then it will assume an active role in the policy-making process. This follows from the impact of crisis on organizational structures. Because the formal decision-making process is constrained under these circumstances, the staff will participate if it has developed an ad hoc independent reputation.

Clearly the relationship between the director and the secretary of state is an intervening variable. If the two men have a close personal relationship, then the staff is likely to participate in crisis decision- making and, further, is likely to have an impact on the direction of foreign policy.

The often cited role of the Kennan-led Policy Planning Staff in the creation of the Marshall Plan illustrates these propositions. The situation in Western Europe immediately following the end of World War II presented American policy-makers with what was perceived as an unambiguous threat. The ad hoc nature of the staff at that time almost guaranteed its impact. In fact, as we have stated, the Policy Planning Staff was created with the explicit purpose of formulating a response to that threat. Because of the close personal relationship between Kennan and Marshall, the staff's impact was direct and immediate. In this situation, perhaps one of the best examples of $\mathrm{s} / \mathrm{P}$ influence in the postwar period, policy planners participated extensively and had a profound impact on the direction of American foreign policy. ${ }^{35}$

\section{PROPOSITION 6}

If a specific issue does not fall within the jurisdiction of a single regional or functional bureau in the Department of State, then the weight of S/P influence increases.

The nature of the issue facing decision-makers, just as the nature of the situation, affects the extent of the Policy Planning Staff's influence on foreign policy. If the issue is inter-office or interdepartmental, then it probably cannot be resolved without being 'kicked upstairs' because interoffice or interdepartmental issues involve increasing numbers of bureaucratic actors with multiple perspectives on the problem. ${ }^{36}$ The lateral bargaining that results provides opportunities for bureaucratic actors outside of the usual line of command to influence policy. Particularly if the Policy Planning Staff has the confidence of the secretary, it can assume an active role in the policy process on these kinds of issues.

A prime example was the Policy Planning Staff's role in the creation of the Development Loan Fund. Under the direction of Robert Bowie, the staff 'worked not as a group of detached men limiting their activity to broad analyses but as an in-house lobby maneuvering its ideas through the bureaucracy. ${ }^{37}$ Most notable were the efforts of Henry Owen and Philip Trezise, who 'engaged in promotional activities to get the proposal into the hands of people who could influence Dulles' calculations, and preventive activities to keep the proposal out of the hands of opponents. ${ }^{38}$ Their success was due in part to the unique character of the Development Loan Fund issue: it did not fall within the operational responsibilities of any single office. ${ }^{39}$

34 The relationship between transitory qualities of the situation confronting decision-makers and the bureaucratic process has been documented in Charles F. Hermann, Crises in Foreign Policy (Indianapolis 196g) and Linda P. Brady, The Situation and Foreign Policy,' in Maurice A. East, Stephen A. Salmore, and Charles F. Hermann, eds, Why Nations Act (Beverly Hills 1977).

35 See Janis, Victims of Groupthink, pp167-81.

36 Destler, Presidents, Bureaucrats, and Foreign Policy, pp 60-1.

$37 \mathrm{Ibid}$, p 225. In addition, see Halperin, Bureaucratic Politics and Foreign Policy, 100.

38 Russell Edgerton, 'Sub-Cabinet Politics and Policy Commitment: The Birth of the Development Loan Fund' (Syracuse

197o), p 160.

39 Ibid, p 171. 


\section{CONCLUSIONS}

This study has sought to address the problem of planning for foreign policy in a more systematic manner than has been done in the past. Rather than focus on specific cases of planning influence or lack of influence, I have identified some causes of success or failure which apply across time and across cases $\sim$ such as the operating style of the director of the Policy Planning Staff, the relationship between the director and the secretary of state, the nature of the situation confronting decision-makers, and the characteristics of the issue under consideration. Although each factor has an independent effect on planning staff influence, two or more factors (such as individual characteristics and organizational arrangements) often interact to produce distinctive planning processes.

The framework presented here represents a marked departure from previous approaches in that it focuses on the planner as a bureaucratic actor. To explain planner influence or lack of influence, one must understand the 'bureaucratics' of the problem; it is not sufficient to view planners as thinkers. To focus on the planner as bureaucratic actor is not to insist on operational involvement in the policy process, but to demand engagement. That is, if he is to be influential the planner must engage in the bureaucratic struggles necessary to gain and maintain access to information and high-level decision-makers. In the absence of this engaged perspective, the planner performs a sterile intellectual exercise.

One of the dangers of engagement, of course, is the risk of overinvolvement, to the detriment of a long-term perspective on foreign policy and to the corruption of an adversary role. At the same time, the risks of engagement must be compared with the consequences of noninvolvement in the policy process. If planners want to influence foreign policy, then they must be willing to take the risks associated with engagement. What this means is that planners will often cross the line between planning and operational responsibilities. This is to be expected. The assumption of operational responsibilities poses a major threat to planning only when those responsibilities are assumed on a day-to-day basis and as a matter of course, rather than in unusual circumstances.

But we began with broader questions as well. How can one apply these insights (based on an analysis of the Policy Planning Staff in the Department of State) to non-s/p planning groups? Do the propositions developed here explain the success or failure of planning groups in other United States government agencies? It is probably too early to give definite answers to these questions. But there are some indications that planning groups in other agencies operate in a manner similar to $\mathrm{s} / \mathrm{P}$. The group that comes closest to $\mathrm{s} / \mathrm{P}$ in responsibilities and in bureaucratic position is the planning staff in the Office of the Assistant Secretary of Defense for International Security Affairs." What distinguishes this group from the State planning staff is 'the knowledge of how to make planning effective. ${ }^{41}$ The bureaucratic skills required to make planning effective are the same for both staffs. But the Defense planning group, in contrast to $\mathrm{s} / \mathrm{P}$, has successfully mobilized those skills. ${ }^{42}$

What is the relevance of this framework to the planning process in other nations? How does one assess its potential for the comparative analysis of foreign-policy planning? To be sure, the

40 Yarmolinsky, 'Bureaucratic Structures and Political Outcomes.'

41 Halperin, Bureaucratic Politics and Foreign Policy, p 228.

42 Yarmolinsky, 'Bureaucratic Structures and Political Outcomes,' p 232. 
relevance of this framework varies from nation to nation. Policy planners in industrialized nations have been forced to cope with similar organizational-bureaucratic conditions. The extent and form of planning in less developed nations, however, may vary dramatically from the industrialized 'norm.' Thus, a framework that applies to one type of nation may be less suitable for another. All of this suggests that as the scope of the inquiry is broadened to include nations with a wide range of attributes, so also must the framework be expanded to include variables that describe different political regimes and economic systems. Although it is difficult, then, I argue that comparative analysis of the planning process is both possible and desirable.

It is ironic, in conclusion, that as the need for planning has grown, the ability to plan has deteriorated. That we live in an interdependent world has become a truism. The abilities of foreign-policy decision-makers to predict future trends and to control events have declined with the growth of interdependence. ${ }^{43}$

Moreover, the effects of interdependence have extended beyond the substance of foreign policies $^{44}$ to the processes by which those policies are made. Uncertainty has made planning more difficult at the same time that it has made planning more crucial. Precisely because of these trends, we should turn our attention to a more systematic analysis of the conditions in which foreign-policy planners are influential. To ignore the problem of planning for foreign policy risks, in the short run, unanticipated consequences and, in the long term, economic and political chaos.

43 Edward L. Morse, Modernization and the Transformation of International Relations (New York 1976), pp 104-6.

44 One consequence has been the interdependence of domestic and foreign policies. The introduction of the term 'intermestic' to describe the new politics and issues that are both domestic and international at the same time illustrates the blurring line between domestic and foreign political processes. See Bayless Manning, 'Goals, Ideology and Foreign Policy,' Foreign Affairs, LIV (January 1976), 271-84. 